\title{
A decade's debate on the nexus between corporate social and corporate financial performance: a critical review of empirical studies 2002 - 2011
}

\author{
Weisheng $\mathrm{Lu}^{1}$; K.W. Chau ${ }^{2}$; Hongdi Wang ${ }^{3}$; Wei Pan ${ }^{4}$
}

\begin{abstract}
Theoretical discussions and empirical studies on the nexus between corporate social responsibility/corporate social performance and corporate financial performance have never ceased since the origin of the concepts. The development trajectories of such studies should be articulated with a view to informing practical corporate social responsibility applications and theoretical studies in the future. This paper presents a critical review of relevant empirical research articles on the nexus between corporate social performance and corporate financial performance published during the ten-year period from 2002 to 2011. Using mixed-methods of content analyses and statistical analyses, the paper reviews 84 empirical studies of this kind published during the period. The results indicate that, despite the enormous amount of previous studies, the corporate social performance and corporate financial performance nexus is a line of inquiry that remains inconclusive. The pattern of corporate social performance-corporate financial performance relationship research in the decade examined has shifted towards exploring the linkages between specific aspects of the two constructs. The positive relationships between these specific aspects in dual directions are confirmed by most of the studies examined in this paper. The paper also examines the impact of time and space change on the corporate social performance-corporate financial performance nexus. The findings show that researchers have gradually recognized that the relationship is not static but changes over time. Furthermore, the paper finds that corporate social responsibility has been increasingly debated in developing countries and in specified industrial settings. The review concludes that to explore the corporate social performance-corporate financial performance nexus by contextualizing it in a specified community, and/or examine its dynamics is a promising
\end{abstract}

\footnotetext{
${ }^{1}$ Assistant Professor, Dept. of Real Estate and Construction, Faculty of Architecture, The University of Hong Kong, Pokfulam, Hong Kong. Email: wilsonlu@hku.hk

${ }^{2}$ Chair Professor, Dept. of Real Estate and Construction, Faculty of Architecture, The University of Hong Kong, Pokfulam, Hong Kong.

${ }^{3} \mathrm{PhD}$ candidate, Dept. of Real Estate and Construction, Faculty of Architecture, The University of Hong Kong, Pokfulam, Hong Kong.

${ }^{4}$ Assistant Professor, Dept. of Civil Engineering, Faculty of Engineering, The University of Hong Kong, Pokfulam, Hong Kong.
} 
research area that can yield significant academic and practical values.

Keywords: Corporate Social Responsibility; Corporate Social Performance; Corporate Financial Performance; Critical Review; Corporate Social Performance - Corporate Financial Performance relationship

\section{Introduction}

Corporate social responsibility (CSR) is the idea of corporations acting in socially responsible ways. While Bowen (1953) is usually credited with coining the modern phrase CSR, discussion of social responsibilities (SR) of executives and business by researchers began in the late 1920s (e.g. Barnard, 1938; Kreps, 1940). The topic has been and remains the subject of continual debate. Friedman (1962), for example, famously argued that socially desirable goals, if at the expense of profitability, should be disconnected from a company's fiduciary responsibilities. He stated that if managers used corporate resources for any cause other than profit maximization, it would constitute a form of theft (Friedman, 1962). The notion of CSR gained momentum in academia when stakeholder theory (Freeman, 1984) came into vogue. According to this theory, stakeholders have different interests in a corporation and thus have different impacts upon it, positive or negative, and the corporation is seen to be responsible to meet their interests. Business executives tend to take an eclectic position, accepting that companies have an obligation to assume social responsibilities while pursuing business success. Porter and Kramer (2006, 2011) have even advocated shifting societal issues from the periphery to the core of a business by 'creating shared value', which involves creating economic value in a way that also creates value for society.

Nowadays, CSR has emerged as "an inescapable priority for business leaders in every country" (Porter and Kramer, 2006, p. 78). In November 2010, the International Organization for Standardization (ISO) launched ISO 26000, providing guidance for businesses and organizations to operate in a socially responsible way. The European Commission (EC) published a renewed 2011-14 European Union (EU) strategy for CSR, requiring that enterprises "should have in place a process to integrate social, environmental, ethical human rights and consumer concerns into their business operations and core strategy in close 
collaboration with their stakeholders" (EC, 2011, p.6). Likewise, the Organization for Economic Co-operation and Development (OECD) in 2011 published the Guidelines for Multinational Enterprises recommending the way in which responsible business should be conducted. Nevertheless, the extent to which companies actually engage in this CSR trend is vigorously disputed. Some argue that CSR could be mere window-dressing; at times, business executives are allegedly myopic in assuming social responsibility (Crowther, 2004; PainterMorland, 2006). In short, CSR needs an economic justification; without evident benefits for companies, CSR may not continue to flourish as CSR programs are costly and must compete for companies' limited financial resources (Wang et al., 2008b). DTI (2002) also pointed out that CSR needs to have a genuine economic foundation to be sustained in a competitive business world.

Partly with the aim to provide this economic justification, researchers have searched for an empirical link between CSR/corporate social performance (CSP) and corporate financial performance (CFP). No consensus exists on what is meant by CSR. Dahlsrud (2008) identified 37 definitions of CSR but Carroll and Shabana (2010, p.3) claimed that this figure underestimates the true number, "because many academically derived definitional constructs were not included”. The one stated by Carroll (1991) has been known by many scholars as the CSR pyramid, which suggests that the social responsibility of business encompasses the economic, legal, ethical, and philanthropic responsibilities. While a consensus of CSR definitions remains an issue, other similar concepts such as CSP, corporate citizenship, and sustainable development (SD) have emerged. Wood (1991, p.693) defines CSP as "a business organization's configuration of principles of social responsibility, process of social responsiveness, and policies, programs, and observable outcomes as they relate to the firm's societal relationships". Although some researchers use CSP and CSR interchangeably in empirical studies (Margolis et al., 2007), others attempt to distinguish the two concepts. For example, according to the definitions offered by Carroll (1991), CSR emphasizes obligation and accountability to society, corporate social responsiveness emphasizes action and activity, while corporate social performance emphasizes outcomes and results. Using a performance measurement system approach, CSR commitment is a leading while CSP is a lagging (actual, objective, and backward-looking) measure (e.g. Chillida, 2009). Likewise, Maron (2006) 
suggested that CSP is a way of making CSR applicable and putting it into practice. CSR is not a variable and therefore it is impossible to measure; CSP, on the other hand, though difficult to measure too, can be surrogated by the use of proxy measurable variables (Beurden and Gössling, 2008). Visser et al. (2010) pointed out that for practical purpose, CSP might be seen as an extension of the concept of CSR, one that focuses on actual results achieved rather than the general nominal notion of businesses' accountability or responsibility to society. Corporate citizenship has been considered as synonymous to corporate social performance (Jacobs and Kleiner, 1995; Lewin et al., 1995). Notably, business executives often use CSR and SD without deliberating their difference. Ebner and Baumgartner (2006) argued that the terms, CSR or SD, should be used in their original semantic sense; scientists, who use CSR synonymously for SD or argue that SD is the basis for CSR, mix up terms and alter their original meaning. We thus exclude the papers tackling SD in this critical review. Further, we maintain the original authors' terms in reporting their CSR/CSP-CFP nexus but for reducing ambiguities, CSR and CSP are aligned to one term - that is CSP. In this sense, CSR and CSP are actually used interchangeably here but readers are suggested to bear these different views in mind when reading this article.

The CSP-CFP link has become a non-trivial issue, widely debated amongst management theorists and business executives. Margolis and Walsh (2001) identified 95 empirical studies on the CSP-CFP relationship published since 1972; in a later study (Margolis and Walsh, 2003), they identified 127 research papers published on this subject. Their research reveals that most of these studies reported 'mixed' results, with positive, negative, or neutral CSP-CFP relationships found. Orlitzky et al. (2003) critiqued that Margolis and Walsh's (2001) study used the so-called 'vote-counting' technique, whereby studies are simply coded as showing significantly positive, negative, or statistically non-significant results, and conclusions are likely to be false. Orlitzky et al. (2003) used meta-analysis, viewing it as a more robust statistical method. In their milestone review they reported, with greater certainty, that CSP is positively correlated with CFP. Research on the relationship continues despite the fact that Margolis and Walsh (2001) and Rowley and Berman (2000) call for a moratorium on CSP-CFP research. Yet, what seems to be missing in the literature is a critical and comprehensive review of the empirical studies undertaken since then. Wu (2006) conducted a meta-analysis of the 
links amongst CSP, CFP, and firm size investigated by 121 empirical studies. The focus of Wu's (2006) study was on firm size as a moderator and it is not entirely clear the time period that his analysis has covered. Beurden and Gössling (2008) undertook a literature review of the studies on the relationship between CSP and CFP since 1990. Nevertheless, its conclusion that 'Good Ethics is Good Business' for the present Western society needs to be further examined by contextualizing it in a broader and more dynamic trend of CSR globalization.

The aim of this paper is to conduct a critical review of previous empirical studies of the CSPCFP relationship, in order to synthesize the research findings over the past decade and to identify new perspectives for future research. The decade examined uses the year 2002 as a point of departure, in order to maintain the continuity of this line of research while avoiding 'reinventing the wheel' given that the milestone studies by Margolis and Walsh (2001) and Orlitzky et al. (2003) have investigated the literature up to the year 2001. The paper is divided into four sections. This introductory section is followed by a detailed description of the methodology. The third section presents the results and discussion, followed by a final section of conclusions and implications for further research. It is found that the CSP-CFP nexus is still a line of inquiry that remains inconclusive over the past decade. Researchers have thus examined the nexus between 'decomposed' aspects of CSR and CFP, and positive relationships between the decomposed CSP and CFP in dual directions are confirmed by most of the studies, while some did argue for a non-significant or a negative relationship. The paper also reveals that researchers have sought answers to the CSP-CFP relationship in the context of a more specified background (e.g. a specific country, or a given industry). A further research trend identified is that previous researchers have gradually recognized that the effects of implementing CSR take time to reflect on CFP, and vice versa.

\section{Research methods}

Firstly, relevant studies on the CSP-CFP relationship were selected. A preliminary computer search using keywords in the following databases: ABI/Inform, ISI Web of Knowledge, EBSCO, and Google Scholar, was carried out to select relevant articles from 2002 to 2011. The keywords for CSR were corporate social respons* (CSR), social respons* (SR), corporate *responsibility, and corporate social performance (CSP), while the keywords used for CFP 
included competitiveness, competitive advantage, financial performance (FP), corporate financial performance (CFP), profitability and productivity. In particular, in order to ensure the comprehensiveness of the studies to be covered, we searched the relevant studies through Google Scholar using these keywords and similar ones such as corporate citizenship, sustainable development, and sustainability. A total of 1,178 journal articles published between 2002 and 2011 were directly retrieved from Google Scholar and the sources listed above. A manual scanning of the abstracts was then conducted. Review articles amongst the 1,178 hits were picked out and scrutinized in order to refine the list of papers. Using the 'citation pearl growing' method (Dolan et al., 2004), the references cited at the end of each review article were compared with our list, so that the chance of missing important articles published in the last decade could be minimized. Those articles without an emphasis on the CSP-CFP relationship were removed from the list. Through these rigorous processes, a list of 84 relevant empirical studies on the CSP-CFP relationship was established.

Secondly, the selected studies were coded using content analysis. The method was developed by Lindesmith (1931) and popularized by Glaser (1965). Jupp (2006, p.40) defined it as “a method of analyzing the contents of documents that uses quantitative measures of the frequency of appearance of particular elements in the text”. It is a systematic, replicable technique for compressing many words of text into fewer content categories based on explicit rules of coding (Stemler, 2001). Content analysis is a continuous and iterative process. Two key stages characterize its course. The first requires managing the data and the second involves making sense of the evidence through descriptive or explanatory accounts. Bryman and Bell (2011) reported that content analysis has several advantages, such as transparency, allowing a certain amount of longitudinal analysis, highly flexible, etc. It thus offers a suitable method for extracting the data from the above empirical papers for further statistical analyses. The process was often assisted by computer assisted qualitative data analysis software (CAQDAS), for example, the popular software tool NVivo ${ }^{\circledR}$. In the course of this study, we engaged a combination of two software tools, Endnote ${ }^{\circledR}$ and Microsoft ${ }^{\circledR}$ Excel, as the working platform, and manually coded and compiled basic information on the 84 selected studies, including Author, Publication Year, Title and Journal, in an Excel file. Other items including Moderating/Control variables, CSR type, CSR measures, CFP type, CFP measures, Data 
sources, Countries or regions of companies, Company sample size, Years for CSR/CFP data, Overall relationship, and Research methods, were also extracted from the articles and collated in the Excel file. Although these studies reported empirical relationships between CSP-CFP, the data was largely textual and could not be extracted without this content analysis process. To reduce potential bias underlying the content analysis, the coding process was manually conducted by two of the authors of this paper. Agreement on the coded contents had to be made through interactions between the two coders. The final versions of the Excel and Endnote files formed an information hub, based on which this critical review is conducted. The files are much similar to the 'monster matrix' that was used by Beurden and Gössling (2008) to describe the paper information in their literature review.

Thirdly, results and findings were drawn through analysis of the article information hub. As it will be elaborated later, empirical examinations of the CSP-CFP relationship have continued to proliferate, and the overall CSP-CFP relationships remain inconclusive. These observations lead to analyses of the 'decomposed' CSP and CFP relationships (Post, 1991), assuming that temporarily we leave aside the question of what the 'decomposed' CSP and CFP really refer to. Unlike previous studies adopting a 'vote-counting' method (e.g. Margolis and Walsh, 2001) or a meta-analysis (e.g. Orlitzky et al., 2003), this research deploys a statistical analysis that takes into consideration both the reported nexus and the sample sizes as included in each empirical study. Specifically, papers falling into a given category of decomposed CSP and CFP relationship were coded into effect value, e.g. 1 for positive, 0 for non-significant, and -1 for negative, by simultaneously considering their sample size. For example, there are five studies examining the CSP disclosure (a 'decomposed' CSP) and market-based CFP (a 'decomposed' CFP) relationship: Prado-Lorenzo et al. (2008) and Wen and Yuan (2008) report a positive relationship; Bruce et al., (2003) and Bruce et al., (2004) report a non-significant relationship; and Siregar and Bachtiar (2010) report a negative relationship between the two. Therefore, the codes for the five studies are 1, 1, 0, 0, and -1. The five studies examined 234, 230, 157, 68, and 87 samples respectively, therefore the total effective sample size for examining the relationship between CSP disclosures and market-based CFP is 776. Next, the weighted mean effect size and homogeneity were calculated using the following equations (1) and (2):

$$
\text { Weighted Mean Effect Size: } \overline{E S}=\frac{\sum w_{i} E S_{i}}{\sum w_{i}}
$$


where $w_{i}$ is the sample size as examined by the article $i, E S_{i}$ is the effect size of article $i$ where $E S_{i}=\left\{\begin{array}{l}1, \text { Positive relationship is found in Article } i \\ 0, \text { No significant relationship is found in Article } i \\ -1, \text { Negative relationship is found in Article } i\end{array}\right.$ $\overline{E S}$ is the weighted mean effect size, and Q is homogeneity test statistics (Ellis, 2010). According to Ellis (2010), a weighted mean effect size reflects the population effect size more accurately than any of the individual estimates. Next, the significance test is conducted using t-test to evaluate whether a relationship is significant or not after putting all the samples together in the statistical analysis. The effect size is assumed to obey $t$-distribution, mathematically expressed in Equation (3):

$\frac{\overline{E S}}{\sqrt[n]{Q / n}} \sim t(n-1)$

Where $\overline{E S}$ and $\mathrm{Q}$ are explained in the Equations (1) and (2) above, $n$ is the total number of studies involved in the investigation. In order to find whether the effective size is significantly positive or not, we have to conduct the significance test as shown in Equation (4)

Significance test: $\operatorname{Pro}\left(\frac{\overline{E S}}{\sqrt{Q / n}}>0\right) \geq 95 \%=>$ Significantly positive

$$
\begin{gathered}
\operatorname{Pro}\left(\frac{\overline{E S}}{\sqrt{Q / n}}<0\right) \geq 95 \%=>\text { Significantly negative } \\
\text { Otherwise, not significant }
\end{gathered}
$$

If $\frac{\overline{E S}}{\sqrt{Q / n}}>0$, we should compare Pro $\left(\frac{\overline{E S}}{\sqrt{Q / n}}>0\right)$, which is the probability of effect size that represents the positive relationship between CSP and CFP at the typical confidence interval of 95\%. Following the above example, the mean effect size is calculated using Equation (1): $\overline{E S}=\frac{\sum w_{i} E S_{i}}{\sum w_{i}}=0.486$, and the Homogeneity is calculated using Equation (2): $Q=\sum w_{i}\left(E S_{i}-\overline{E S}\right)^{2}=0.474$. Under the assumption of $t(5-1)$, the threshold value of unilateral $t$ distribution is 2.132 at $95 \%$ confidence. Through calculating the value of $\frac{\overline{E S}}{\sqrt{Q / n}}$, we can find that $\frac{\overline{E S}}{\sqrt{Q / n}}=1.578<2.132$, which means that Pro $\left(\frac{\overline{E S}}{\sqrt{Q / n}}>0\right)<95 \%$. Therefore, the significance test indicates that the relationship between CSP disclosures and market-based CFP is not significant. This statistical analysis thus alleviates the problems inherent in the 'vote- 
counting' method by considering the sample sizes investigated by each individual study. It also overcomes the problem that the sample sizes will be insufficient for a meta-analysis of the decomposed CSP and CFP relationships.

Given that CSP will not explain all the variations in CFP across companies, and vice versa, control variables have often been adopted by previous studies. For example, Andersen and Dejoy (2011) summarized that size, industry, risk, R\&D and advertising expenses are the most commonly used control variables. This literature review thus examined the control variables as used by the 84 empirical studies. The paper further investigated the impact of time and space change on the CSP-CFP nexus. In addition to the aforementioned statistical analyses, this paper adopted similar processes that are commonly found in literature studies to analyze the information as stored in the article information hub. The results were triangulated with existing review papers on the subject, such as those authored by Wu (2006), and Beurden and Gössling (2008), and empirical studies, such as Saether and Aguilera (2008), Ciliberti et al. (2008), Cramer (2008), Jenkins and Yakovleva (2006), and Lambooy (2011). Moreover, early works such as those of Conine and Madden (1987), Davidson and Worrell (1990), Reimann (1975), Waddock and Graves (1997), Cochran and Wood (1984), and Wartick (1988), depending on their relevance and significance, were included in the triangulation. But readers are reminded that the focus of this literature review lies on the 84 empirical studies. The three parts of data, namely, the 84 empirical studies on the CSP-CFP nexus, existing review papers, and other empirical studies on CSR, were blended together to ensure an uninterrupted reading journey in understanding the impact of time and space change on the relationship between CSP and CFP.

\section{Results and discussions}

As can be seen from Figure 1, empirical examinations of the CSP-CFP relationship have continued to proliferate, irrespective of the previous calls for a moratorium on CSP-CFP research. Both Margolis and Walsh (2001) and Orlitzky et al. (2003) have explored the overall relationship between CSR and CFP, which can be divided into three categories: positive, negative, and non-significant. In a similar vein, we examined the 84 empirical studies with a view to seeing whether the inquiry of the CSP-CFP nexus has been concluded in the past decade. 


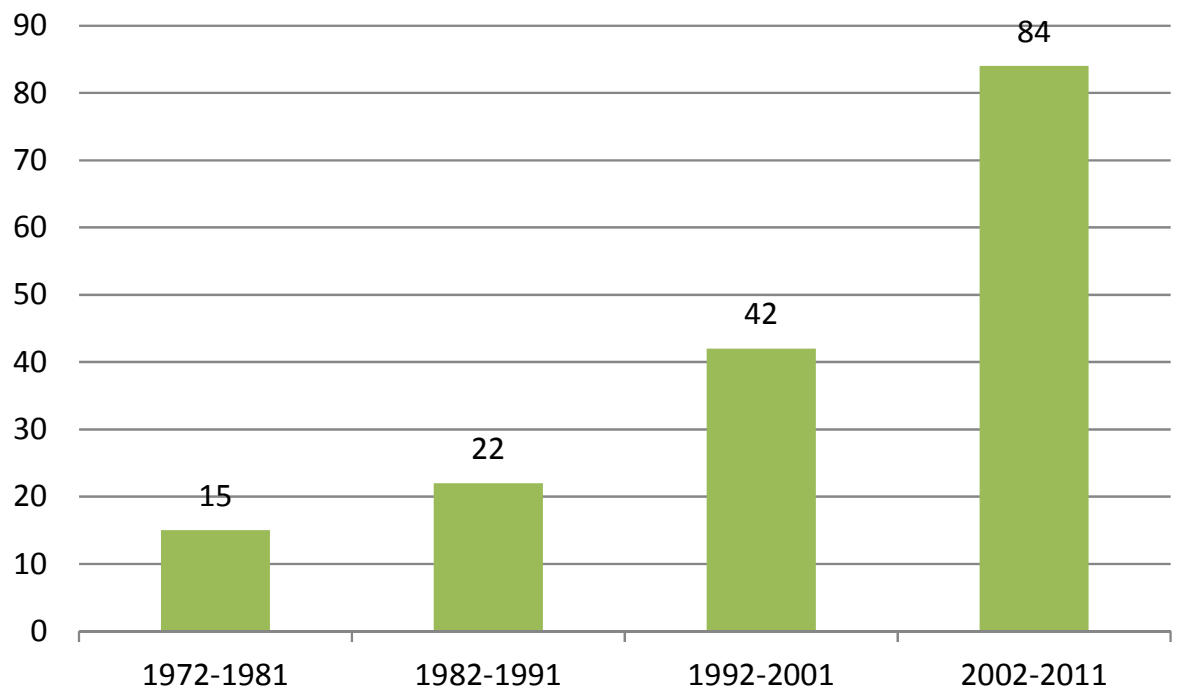

Figure 1 The numbers of empirical studies over the past four decades The data for 1972-1981, 1982-1991, and 1992-2001 is from Allouche and Laroche (2005) while the data for 2002-2011 is based on our search.

\subsection{Overall CSP-CFP relationships}

The results of the authors' exploration of the overall CSP-CFP relationships in the 84 reviewed studies between 2002 and 2011 are shown in Table 1. All of the articles except for one investigate the causality of CSP on CFP, and a positive causal relationship between CSP and CFP is confirmed by the majority. However, there is also a relatively large number of articles (21) reporting a non-significant causality of CSP on CFP. Only a very small number of articles point to a negative relationship between CSP on CFP. Conversely, only 25 studies amongst the 84 consider the impact of CFP on CSP. Amongst them, 15 studies confirm the positive impact of CFP on CSP.

Table 1 A summary of the overall CSP-CFP relationship in the 84 studies

\begin{tabular}{llllll}
\hline Causality & Not examined & Negative & Non-significant & Positive & Other $^{\&}$ \\
\hline CSP->CFP & 1 & 6 & 21 & 38 & 18 \\
CFP->CSP & 59 & 2 & 8 & 15 & 0 \\
\hline
\end{tabular}

\footnotetext{
${ }^{\&}$ Relationship other than the positive, negative, or non-significant ones

\# CSR->CFP indicates the causality of CSP on CFP

+ CFP->CSR indicates the causality of CFP on CSP
} 
Orlitzky et al. (2003) explored, in particular, the bidirectional causality between CSP and CFP. By examining the bidirectional causality within the same company, it is possible to see whether there is a virtuous or vicious cycle between the two variables with quick cycle times or concurrent bidirectionality. Orlitzky et al. (2003) reported that CSP and CFP mutually affect each other through a virtuous cycle: financially successful companies spend more because they can afford it, but CSP also helps them become slightly more successful. Amongst the 84 studies under research, 37 examine the bidirectionality between CSP and CFP. Within these 37 studies, the detailed causal relationships in two directions diversify in different combinations (e.g. positive for CSP->CFP but negative for CFP->CSP), making it impossible to draw a conclusion on whether there is a virtuous or vicious cycle between CSP and CFP. For the sake of simplicity, the detailed combinations of the casual relationships are not discussed here.

The research findings thus somewhat contradict Beurden and Gössling’s (2008) work, which reveals that there is indeed clear empirical evidence for a positive correlation between corporate social and financial performance. These findings, however, are not significantly different from those of Margolis and Walsh (2001) and Orlitzky et al. (2003). Persistent inquiries into the overall relationship between CSR and CFP thus seem futile, and this leads to analyses of the 'decomposed' CSR and CFP relationships.

\section{2 'Decomposed' CSP-CFP relationships}

Given that research on the relationship between CSP and CFP remains largely inconclusive, researchers in the reviewed studies have looked into the relationships between CSP and CFP subsets, which are termed 'decomposed' CSP and CFP respectively.

\subsection{1 'Decomposed' CSP}

As shown in Table 2, the CSP used in the reviewed studies can roughly be decomposed into four types, namely, a) CSP disclosures; b) CSP reputation ratings including KLD, Fortune, and other rating databases; c) Social audits, CSP processes, and observable outcomes; and d) other types defined by different authors. The first three are largely in line with Post's (1991) broad measurement strategies, which were also directly cited in Orlitzky et al. (2003). 
Table 2 A summary of the frequently used CSR types and their measures (CSP)

\begin{tabular}{|c|c|c|c|c|c|c|c|c|c|c|c|c|}
\hline \multicolumn{13}{|c|}{ Year } \\
\hline & & 於 & స్ & $\begin{array}{l}N \\
\stackrel{8}{\circ} \\
\perp\end{array}$ & $\begin{array}{l}N \\
\stackrel{0}{0} \\
\text { บ }\end{array}$ & 용 & 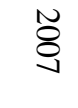 & $\begin{array}{l}N \\
\varnothing \\
\varnothing\end{array}$ & No & $\stackrel{N}{\stackrel{O}{O}}$ & $\stackrel{N}{\stackrel{\ominus}{\ominus}}$ & $\stackrel{-1}{\stackrel{0}{3}}$ \\
\hline \multirow{4}{*}{$\begin{array}{l}\text { CSP } \\
\text { Types }\end{array}$} & a) CSP disclosures & 1 & 1 & 2 & 0 & 0 & 2 & 3 & 0 & 5 & 1 & 15 \\
\hline & b) CSP reputation ratings & 0 & 0 & 0 & 0 & 2 & 3 & 8 & 11 & 8 & 4 & 37 \\
\hline & $\begin{array}{l}\text { c) Social audits, CSP processes, and } \\
\text { observable outcomes }\end{array}$ & 0 & 0 & 1 & 2 & 0 & 0 & 1 & 1 & 1 & 2 & 9 \\
\hline & d) Particularly defined by authors & 1 & 0 & 1 & 0 & 3 & 3 & 4 & 7 & 4 & 5 & 29 \\
\hline
\end{tabular}

(Note: There are 6 studies using two types of CSP, therefore the total number is $84+6=90$ )

In the reviewed studies, it is noticed that studies of the empirical CSP-CFP link often adopt a pragmatic approach to circumvent measuring problems, using aggregated CSR indices established by other parties. It is evident from Table 2 that the most frequently used CSR measurement variables are the CSP reputation ratings using indexing techniques, e.g. the direct scores given by the accessible databases, such as KLD and Fortune 500, and the indirect coding of CSR disclosures and social observations according to the various CSR-related perspectives categorized by these databases. According to Orlitzky et al. (2003), social audits consist of a systematic third-party effort to assess a firm's 'objective' CSP behaviors, such as community service, environmental programmes, and corporate philanthropy. Social audits differ from CSP disclosures in that the former are imposed by a third party while the latter are largely self-reported.

In analyzing the studies on the CSP-CFP relationship from 2002 to 2011, one notably new research finding is that a large proportion of the reviewed studies (29 out of 84) have attempted to define their own CSR measures, as shown in d) in Table 2. In these studies, CSP is measured by: (1) a scaling technique to assess specific aspects of social performance similar to that used by KLD and Fortune 500 (De-los-Ángeles Gil-estallo et al., 2009; Hull and Rothenberg, 2008; Mishra and Suar, 2010; Simpson and Kohers, 2002), (2) self-defined sustainable indicators (Rettab et al., 2011; Yu et al., 2009; Zheng, 2006), (3) coding of conduct according to the institutional conditions (Chih et al., 2010; Choi and Jung, 2008; Godfrey et al., 2009; Pae and Choi, 2011), and (4) dichotomous or dummy variables to identify whether certain CSR 
principles are adopted (Barnett and Salomon, 2006; Byus et al., 2010; Greig, 2006; Mittal et al., 2008).

Which CSR measures are adopted is also determined by data availability. There are three major CSR data sources: $49 \%$ of the observations come from the results of CSR advisory databases, such as KLD, Fortune 500, Dow Jones Sustainability Index (DJSI), Taft's Directory of Corporate Giving, Canadian Social Investment Database, and some magazines/papers; 18\% from corporate annual reports or corporate websites and press releases; and 14\% from survey respondents. Resonated with the findings of Margolis and Walsh (2003) and Wu (2006), the KLD rating database is the most popular data source. The pluralism of CSR measures reflects the cumbersome absence of a single agreed definition of CSR among researchers and practitioners, even after the lapse of decades since the emergence of the concept. Without this consensus, CSR definitions and the CFP measures will continue to diversify.

\subsection{2 'Decomposed' CFP}

As shown in Table 3, most of the CFP definitions and their corresponding measures in the reviewed empirical studies can be decomposed into the three-group classification made by Orlitzky (2003), namely, 1) market-based, 2) accounting-based, and 3) perceptual CFP measures. In contrast to the pluralism of CSR measures, measures of CFP in academic research have largely converged into the trichotomy of CFP proposed by Orlitzky et al. (2003). Marketbased measures of CFP, such as price per share or share price appreciation, reflect the notion that shareholders are a primary stakeholder group (Cochran and Wood, 1984). Beurden and Gössling (2008) added more market-based measures in their review work, including stock performance, market return, market value to book value, and others. Alternatively, accountingbased measures consist of profitability measures, asset utilization, such as return on asset (ROA) and asset turnover, and growth measures (Wu, 2006). This echoes with Cochran and Wood (1984) that accounting-based indicators, such as the firm's return on assets (ROA), return on equity (ROE), or earnings per share (EPS), capture a firm's internal efficiency in some way.. Lastly, perceptual measures of CFP ask survey respondents to provide subjective estimates of firms' financial performance, for instance, soundness of financial position, wise use of corporate assets, or financial goal achievement relative to competitors (Conine and Madden, 1987; Reimann, 1975; Wartick, 1988). New perceptual CFP measures are adopted by 
the reviewed studies, e.g. 'scaling of financial performance' rated by surveyed respondents.

Table 3 A summary of the frequently used CFP types and their measures

\begin{tabular}{|c|c|c|c|c|c|c|c|c|c|c|c|c|}
\hline & & \multicolumn{11}{|c|}{ Year } \\
\hline & & 용 & స్త & N & No & 용 & 용 & N & 옹 & $\stackrel{\text { N }}{\stackrel{0}{0}}$ & $\stackrel{\text { }}{\ominus}$ & ํㅓㄹ \\
\hline \multirow{3}{*}{$\begin{array}{l}\text { CFP } \\
\text { Type }\end{array}$} & 1) market-based & 0 & 1 & 0 & 1 & 5 & 2 & 10 & 5 & 9 & 6 & 39 \\
\hline & 2) accounting-based & 2 & 1 & 2 & 1 & 1 & 5 & 13 & 12 & 12 & 7 & 56 \\
\hline & 3) perceptual measures & 0 & 0 & 0 & 1 & 0 & 1 & 0 & 5 & 1 & 2 & 10 \\
\hline
\end{tabular}

(Note: There are 21 studies using two types of CFP, therefore the total number is $84+21=105$ )

Amongst the three generic CFP measures, the accounting-based measures are objective and audited, market-based measures are partly objective, and perceptual are largely subjective based on the survey respondents' perceptions. Authors thus use them for different purposes. For example, Davidson and Worrell (1990) use the market measurements, while Beurden and Gössling (2008) use both the market-based and the accounting-based measures. Generally, the reviewed studies tend to combine the different types of measures, either market or accountingbased or perceptual (e.g. Luken and Stares, 2005; Scholtens, 2008; Nelling and Webb, 2009). In so doing, weaknesses in one type of performance measure can be alleviated to some extent by the use of another (McWilliams et al., 2006, McGuire et al., 1988). This can be seen from Table 3; 21 studies use two types of CFP, therefore the total number of studies is $84+20=105$. Specifically, of the three types of CFP measures, accounting-based ones are the most frequently used (56 out of 105), followed by the market-based measures (39 out of 105), and perceptual measures (10 out of 105), as shown in Table 3. It is the stance of the authors to suggest using more objective CFP measures in future studies given that both CSP and CFP are already broad constructs that are difficult to be measured.

Similar to the measures of decomposed CSP, the selection of CFP measures is also subject to data availability. CFP data is mainly derived from financial databases, such as Compustat, U.K. FTSE index from DataStream, WIND, CCER, SABI, BANKSCOPE, Reuters Hindsight financial database, Eurostat's New Cronos database and CFMRC. Other CFP data, in particular 
for the perceptual measures, is collected from corporate annual reports or survey respondents. Overall, Compustat is the most frequently used CFP data source. Previous literature studies seem failing to consider the importance of data sources for CFP measures, particularly when it comes to empirical examination of the CSP-CFP nexus.

\subsubsection{Control variables}

As seen from Table 4, size, industry, capital structure, financial return (ROA, ROE, ROS and EPS) and risk are the top five most frequently used control variables in explaining the CSPCFP relationship. This largely confirms Andersen and Dejoy's (2011) summary that size, industry, risk, $R \& D$ and advertising expenses are the most commonly used control variables. Capital structure is interpreted here as leverage or equity-debt ratio, which has been used to measure risk in some of the reviewed studies (Zheng, 2006; Choi and Jung, 2008; Makni et al., 2009; Choi et al., 2010; Busch and Hoffmann, 2011; Pae and Choi, 2011). Some other control variables are included in these studies and identified as important, such as firm age, ownership, return rate and growth rate.

Table 4 Control variables and their frequencies of appearance

\begin{tabular}{|c|c|}
\hline Control variables & Frequency of appearance \\
\hline Size (firm size) & 50 \\
\hline Industry & 38 \\
\hline Captial structure & 24 \\
\hline Financial return (ROA, ROE, ROS, EPS) & 15 \\
\hline Risk & 14 \\
\hline R\&D intensity & 9 \\
\hline Firm age & 8 \\
\hline Growth rate & 6 \\
\hline Ownership & 6 \\
\hline Advertising intensities & 3 \\
\hline Community size / population & 3 \\
\hline Country and country-based features & 3 \\
\hline \multicolumn{2}{|c|}{$\begin{array}{l}\text { Other control variables that cannot be included as any of the ones listed above: } \\
\text { Market conditions (3), Frequency of nomination on rating list (2), Management support, Dividend payout, } \\
\text { Corporate liquidity, Capital gearing, Business cycle, Geographic location (local or international), Horizontal } \\
\text { and vertical export market scope, Equator or Wolfsberg Principles measures, and Time invariant firm } \\
\text { idiosyncratic characteristics. }\end{array}$} \\
\hline
\end{tabular}




\subsubsection{The 'decomposed' CSP-CFP relationships}

There are four types of decomposed CSP, namely, a) CSP disclosures, b) CSP reputation ratings, c) Social audits, CSP processes, and observable outcomes, and d) those defined by authors, and three types of decomposed CFP: 1) market-based, 2) accounting-based, and 3) perceptual measures. Therefore, considering the duality of causality, there are 24 different combinations of the 'decomposed' CSP-CFP relationships to be examined on the two individual directions, namely, from a decomposed CSP to a decomposed CFP, and from a decomposed CFP to a decomposed CSP. By applying the statistical method as introduced in the methodology section to all the articles, Table 5 is derived.

Table 5 Significance test results of the relationships between decomposed CSP and CFP

\begin{tabular}{|c|c|c|c|c|c|c|}
\hline \multicolumn{2}{|c|}{$\begin{array}{l}\text { Decomposed Relationships as } \\
\text { indicated by individual studies } \\
\text { ( } 4 \text { decomposed } \mathrm{CSP} \times 3 \text { decomposed } \\
\mathrm{CFP} \times 2 \text { directions }=24 \text { combinations) }\end{array}$} & Articles & $\begin{array}{l}\text { Over } \\
\text { all } \\
\text { Sam } \\
\text { ple } \\
\text { size }\end{array}$ & $\begin{array}{l}\text { Weighte } \\
\text { d Mean } \\
\text { Effect } \\
\text { Size } \\
\text { (ES) }\end{array}$ & $\begin{array}{l}\text { Homog } \\
\text { eneity } \\
(Q)\end{array}$ & $\begin{array}{l}\text { Significanc } \\
\text { e test }\end{array}$ \\
\hline \multirow{3}{*}{$\begin{array}{l}\text { CSP disclosures-> } \\
\text { market-based CFP }\end{array}$} & Positive & $\begin{array}{l}\text { Prado-Lorenzo et al., 2008; Wen and } \\
\text { Yuan, } 2008\end{array}$ & \multirow{3}{*}{619} & \multirow{3}{*}{0.609} & \multirow{3}{*}{0.519} & \multirow{3}{*}{$\begin{array}{l}\text { Not } \\
\text { significant }\end{array}$} \\
\hline & Not significant & Bruce et al., 2003 & & & & \\
\hline & Negative & Sylvia and Yanivi, 2010 & & & & \\
\hline \multirow{3}{*}{$\begin{array}{l}\text { CSP disclosures-> } \\
\text { accounting-based } \\
\text { CFP }\end{array}$} & Positive & $\begin{array}{l}\text { Goll and Rasheed, 2004; WEN and Yuan, } \\
\text { 2008; Yang et al., } 2010\end{array}$ & \multirow{3}{*}{2775} & \multirow{3}{*}{-0.032} & \multirow{3}{*}{0.447} & \multirow{3}{*}{$\begin{array}{l}\text { Not } \\
\text { significant }\end{array}$} \\
\hline & Not significant & $\begin{array}{l}\text { Campbell et al., 2002; Bruce et al., 2003; } \\
\text { Bruce et al., 2004; Goll and Rasheed, } \\
\text { 2004; Fauzi et al., 2007; Prado-Lorenzo et } \\
\text { al., } 2008\end{array}$ & & & & \\
\hline & Negative & Sylvia and Yanivi, 2010; Huang, 2010 & & & & \\
\hline \multirow{3}{*}{$\begin{array}{l}\text { CSP disclosures-> } \\
\text { perceptual CFP } \\
\text { measures }\end{array}$} & Positive & Boehe and Barin, 2010 & \multirow{3}{*}{252} & \multirow{3}{*}{-} & \multirow{3}{*}{-} & \multirow{3}{*}{-} \\
\hline & Not significant & nil & & & & \\
\hline & Negative & nil & & & & \\
\hline \multirow{3}{*}{$\begin{array}{l}\text { CSP reputation } \\
\text { ratings-> market- } \\
\text { based CFP }\end{array}$} & Positive & $\begin{array}{l}\text { Stephen et al., 2006; McPeak and Tooley, } \\
\text { 2008; Lee and Park, 2009; Choi et al., } \\
\text { 2010; Gallego-Alvarez et al., 2010; } \\
\text { Salama et al., 2011; Wang et al., 2011; } \\
\text { Ortas and Moneva, 2011 }\end{array}$ & \multirow{3}{*}{$\begin{array}{l}2085 \\
2\end{array}$} & \multirow{3}{*}{0.300} & \multirow{3}{*}{0.487} & \multirow{3}{*}{$\begin{array}{l}\text { Not } \\
\text { significant }\end{array}$} \\
\hline & Not significant & $\begin{array}{l}\text { Moneva et al., 2007; Kristoffersen et al., } \\
\text { 2008; Scholtens, 2008; May and Khare, } \\
\text { 2008; Lee and Park, 2009; Park and Lee, } \\
\text { 2009;Boesso and Michelon, 2010; Surroca } \\
\text { et al., 2010; Ortas and Moneva, } 2011\end{array}$ & & & & \\
\hline & Negative & $\begin{array}{l}\text { Stephen et al., 2006; Luo and } \\
\text { Bhattacharya, 2006; Surroga and Tribo, } \\
\text { 2008; Makni et al., 2009; McPeak et al., }\end{array}$ & & & & \\
\hline
\end{tabular}




\begin{tabular}{|c|c|c|c|c|c|c|}
\hline & & 2010. & & & & \\
\hline \multirow{3}{*}{$\begin{array}{l}\text { CSP reputation } \\
\text { ratings-> } \\
\text { Accounting-based } \\
\text { CFP }\end{array}$} & Positive & $\begin{array}{l}\text { MLopez et al., 2007; Prior et al., 2008; } \\
\text { Chang and Kuo, 2008; McPeak and } \\
\text { Tooley, 2008; Lee and Park, 2009; Paul } \\
\text { and Barbara, 2009; Zhang and Rezaee, } \\
\text { 2009; Peters and Mullen, 2009; Choi et } \\
\text { al., 2010; Moneva and Ortas, 2010; El } \\
\text { Ghoul et al., } 2011\end{array}$ & \multirow{3}{*}{$\begin{array}{l}6612 \\
3\end{array}$} & \multirow[t]{3}{*}{0.786} & \multirow[t]{3}{*}{0.210} & \multirow[t]{3}{*}{ Positive } \\
\hline & Not significant & $\begin{array}{l}\text { Moneva et al., 2007; Becchetti et al., } \\
\text { 2008; Scholtens, 2008; May and Khare, } \\
\text { 2008; Fauzi, 2009; Lee and Park, 2009; } \\
\text { Makni et al., 2009; Boesso and Michelon, } \\
2010\end{array}$ & & & & \\
\hline & Negative & Surroga and Tribo, 2008 & & & & \\
\hline \multirow{3}{*}{$\begin{array}{l}\text { CSP reputation } \\
\text { ratings-> } \\
\text { Perceptual CFP } \\
\text { measures }\end{array}$} & Positive & Duhe, 2009; Boehe and Barin, 2010 & \multirow{3}{*}{958} & \multirow{3}{*}{1.000} & \multirow{3}{*}{0} & \multirow{3}{*}{ Positive } \\
\hline & Not significant & nil & & & & \\
\hline & Negative & nil & & & & \\
\hline \multirow{3}{*}{$\begin{array}{l}\text { Social audits, CSP } \\
\text { processes, and } \\
\text { observable } \\
\text { outcomes } \\
\text { Market-based } \\
\text { CFP } \\
\end{array}$} & Positive & Wen and Yuan, 2008 & \multirow{3}{*}{230} & \multirow{3}{*}{-} & \multirow[b]{3}{*}{-} & \multirow{3}{*}{-} \\
\hline & Not significant & nil & & & & \\
\hline & Negative & nil & & & & \\
\hline \multirow{3}{*}{$\begin{array}{l}\text { Social audits, CSP } \\
\text { processes, and } \\
\text { observable } \\
\text { outcomes -> } \\
\text { Accounting-based } \\
\text { CFP }\end{array}$} & Positive & $\begin{array}{l}\text { Goll and Rasheed, 2004; Brammer and } \\
\text { Millington, 2005; Peinado-Vara, 2006; } \\
\text { Wen and Yuan, 2008; Moneva and Ortas, } \\
2010\end{array}$ & \multirow[t]{3}{*}{1596} & \multirow[t]{3}{*}{0.961} & \multirow[t]{3}{*}{0.018} & \multirow[t]{3}{*}{ Positive } \\
\hline & Not significant & Goll and Rasheed, 2004 & & & & \\
\hline & Negative & nil & & & & \\
\hline \multirow{3}{*}{\begin{tabular}{lr|}
$\begin{array}{l}\text { Social audits, CSP } \\
\text { processes, }\end{array}$ & and \\
observable & \\
outcomes & $->$ \\
Perceptual & CFP \\
measures &
\end{tabular}} & Positive & $\begin{array}{l}\text { Luken and Stares, 2005; Okamoto, 2009; } \\
\text { Boehe and Barin, } 2010\end{array}$ & \multirow{3}{*}{3046} & \multirow{3}{*}{1.000} & \multirow{3}{*}{0} & \multirow{3}{*}{ Positive } \\
\hline & Not significant & nil & & & & \\
\hline & Negative & ( & & & & \\
\hline \multirow{3}{*}{$\begin{array}{l}\text { Authors self- } \\
\text { defined CSP-> } \\
\text { Market-based } \\
\text { CFP }\end{array}$} & Positive & $\begin{array}{l}\text { Schnietz and Epstein,2005;Barnett and } \\
\text { Salomon, 2006; Mahoney et al., 2008; } \\
\text { Callan and Thomas, 2009; Godfrey et al., } \\
\text { 2009; Byus et al., 2010; Pae and Choi, } \\
2011\end{array}$ & \multirow[t]{3}{*}{6451} & \multirow{3}{*}{-.0081} & \multirow[t]{3}{*}{0.275} & \multirow{3}{*}{$\begin{array}{l}\text { Not } \\
\text { significant }\end{array}$} \\
\hline & Not significant & $\begin{array}{l}\text { Greig, 2006; Choi and Jung, 2008; Mittal } \\
\text { et al., 2008; Godfrey et al., 2009; Busch } \\
\text { and Hoffmann, } 2011\end{array}$ & & & & \\
\hline & Negative & Barnett and Salomon, 2006; Zheng, 2006 & & & & \\
\hline \multirow{3}{*}{$\begin{array}{l}\text { Authors self- } \\
\text { defined CSP-> } \\
\text { Accounting-based } \\
\text { CFP }\end{array}$} & Positive & $\begin{array}{l}\text { Simpson and Kohers, 2002; Callan and } \\
\text { Thomas, 2009; Mishra and Suar, 2010; } \\
\text { Byus et al., 2010; Chen and Wang, 2011; } \\
\text { Pae and Choi, 2011 }\end{array}$ & \multirow{3}{*}{3803} & \multirow{3}{*}{0.510} & \multirow{3}{*}{0.250} & \\
\hline & Not significant & $\begin{array}{l}\text { Choi and Jung, 2008; Mittal et al., 2008; } \\
\text { Hull and Rothenberg, 2008; De-los- } \\
\text { Ángeles Gil-estallo et al., 2009; Yu et al., } \\
\text { 2009; Chih et al., 2010; Busch and } \\
\text { Hoffmann, } 2011\end{array}$ & & & & Positive \\
\hline & Negative & nil & & & & \\
\hline $\begin{array}{lr}\text { Authors } & \text { self- } \\
\text { defined } & \text { CSP-> }\end{array}$ & Positive & $\begin{array}{l}\text { He et al., 2007; Wagner, 2009; Fauzi and } \\
\text { Idris, 2009; Rettab et al., } 2009\end{array}$ & 3048 & 0.605 & 0.312 & $\begin{array}{l}\text { Not } \\
\text { significant }\end{array}$ \\
\hline
\end{tabular}




\begin{tabular}{|c|c|c|c|c|c|c|}
\hline \multirow{2}{*}{$\begin{array}{l}\text { Perceptual CFP } \\
\text { measures }\end{array}$} & Not significant & Wagner, 2009; Delmas et al., 2011 & & & & \\
\hline & Negative & nil & & & & \\
\hline \multirow{3}{*}{$\begin{array}{l}\text { Market-based } \\
\text { CFP -> CSP } \\
\text { disclosures }\end{array}$} & Positive & nil & \multirow{3}{*}{244} & \multirow{3}{*}{-} & \multirow{3}{*}{-} & \multirow{3}{*}{-} \\
\hline & Not significant & nil & & & & \\
\hline & Negative & Sylvia and Yanivi, 2010 & & & & \\
\hline \multirow{3}{*}{$\begin{array}{l}\text { Market-based } \\
\text { CFP -> CSP } \\
\text { reputation ratings }\end{array}$} & Positive & $\begin{array}{l}\text { Scholtens, 2008; Surroga and Tribo, 2008; } \\
\text { May and Khare, 2008; Salama et al., 2011 }\end{array}$ & \multirow{3}{*}{9208} & \multirow{3}{*}{0.873} & \multirow{3}{*}{0.110} & \multirow{3}{*}{ Positive } \\
\hline & Not significant & $\begin{array}{l}\text { Boesso and Michelon, 2010; Surroca } \\
\text { al., } 2010\end{array}$ & & & & \\
\hline & Negative & nil & & & & \\
\hline \begin{tabular}{lr}
\multicolumn{2}{l}{ Market-based } \\
CFP $\quad>$ & Social \\
audits, & CSP \\
processes, & and \\
observable & \\
outcomes & \\
\end{tabular} & \multicolumn{6}{|l|}{ nil } \\
\hline \multirow{3}{*}{$\begin{array}{l}\text { Market-based } \\
\text { CFP -> Authors } \\
\text { self-defined CSP }\end{array}$} & Positive & Mahoney et al., 2008 & \multirow{3}{*}{292} & \multirow{3}{*}{0.151} & \multirow{3}{*}{0.170} & \multirow{3}{*}{$\begin{array}{l}\text { Not } \\
\text { significant }\end{array}$} \\
\hline & Not significant & Choi and Jung, 2008 & & & & \\
\hline & Negative & nil & & & & \\
\hline \multirow{3}{*}{$\begin{array}{l}\text { Accounting-based } \\
\text { CFP -> CSP } \\
\text { disclosures }\end{array}$} & Positive & $\begin{array}{l}\text { Bruce et al., 2003; Bruce et al., 2004; } \\
\text { Kobeissi and Damanpour, 2007; } \\
\text { Güler et al., } 2010\end{array}$ & \multirow{3}{*}{14864} & \multirow{3}{*}{0.954} & \multirow{3}{*}{0.053} & \multirow{3}{*}{ Positive } \\
\hline & Not significant & Fauzi et al., 2007 & & & & \\
\hline & Negative & $\begin{array}{l}\text { Sylvia and Yanivi, 2010; Güler et al., } \\
2010\end{array}$ & & & & \\
\hline \multirow[t]{3}{*}{$\begin{array}{l}\text { Accounting-based } \\
\text { CFP -> CSP } \\
\text { reputation ratings }\end{array}$} & Positive & $\begin{array}{l}\text { Kobeissi and Damanpour, 2007; Prior } \\
\text { et al., 2008; Scholtens, 2008; Surroga } \\
\text { and Tribo, 2008; May and Khare, } \\
\text { 2008; Chang and Kuo, 2008; Paul and } \\
\text { Barbara, 2009 }\end{array}$ & \multirow[t]{3}{*}{24701} & \multirow[t]{3}{*}{0.977} & 0.022 & Positive \\
\hline & Not significant & Boesso and Michelon, 2010 & & & & \\
\hline & Negative & nil & & & & \\
\hline $\begin{array}{lr}\text { Accounting-based } \\
\text { CFP } \rightarrow & \text { Social } \\
\text { audits, } & \text { CSP } \\
\text { processes, } & \text { and } \\
\text { observable } & \\
\text { outcomes } & \\
\end{array}$ & nil & & & & & \\
\hline & Positive & $\begin{array}{l}\text { Simpson and Kohers, 2002; Chen and } \\
\text { Wang, } 2011\end{array}$ & & & & \\
\hline $\begin{array}{l}\text { CFP -> Authors } \\
\text { self-defined CSP }\end{array}$ & Not significant & $\begin{array}{l}\text { Choi and Jung, 2008; Yu et al., 2009; } \\
\text { Chih et al., } 2010\end{array}$ & 1792 & 0.372 & 0.233 & $\begin{array}{l}\text { Not } \\
\text { significant }\end{array}$ \\
\hline & Negative & nil & & & & \\
\hline $\begin{array}{ll}\text { Perceptual } & \text { CFP } \\
\text { measures -> } & \text { CSP } \\
\text { disclosures } & \\
\end{array}$ & nil & & & & & \\
\hline & Positive & Duhe, 2009 & & & & \\
\hline measures -> CSP & Not significant & nil & 706 & - & - & - \\
\hline reputation ratings & Negative & nil & & & & \\
\hline Perceptual CFP & Positive & Wagner, 2009 & 2905 & - & - & - \\
\hline
\end{tabular}




\begin{tabular}{|c|c|c|c|c|c|c|c|}
\hline \multirow{2}{*}{\multicolumn{2}{|c|}{$\begin{array}{lr}\text { measures } & -> \\
\text { Social audits, CSP } \\
\text { processes, and } \\
\text { observable } \\
\text { outcomes }\end{array}$}} & Not significant & nil & & & & \\
\hline & & Negative & nil & & & & \\
\hline \multirow{3}{*}{$\begin{array}{l}\text { Perceptual } \\
\text { measures } \\
\text { Authors } \\
\text { defined CSP }\end{array}$} & \multirow{3}{*}{$\begin{array}{r}\text { CFP } \\
-> \\
\text { self- }\end{array}$} & Positive & Fauzi and Idris, 2009 & \multirow{3}{*}{2173} & \multirow{3}{*}{0.036} & \multirow{3}{*}{0.035} & \multirow{3}{*}{$\begin{array}{l}\text { Not } \\
\text { significant }\end{array}$} \\
\hline & & Not significant & Wagner, 2009 & & & & \\
\hline & & Negative & & & & & \\
\hline
\end{tabular}

Confidence degree is $95 \%$.

$\mathrm{x}->\mathrm{y}$ means the impact of $\mathrm{x}$ on $\mathrm{y}$.

nil $=$ no research falling in this kind

- = Significance test not conducted

Some interesting findings emerge from the statistical analysis. For example, a positive relationship in statistical terms at a confidence degree of $95 \%$ is confirmed between some decomposed CSP and CFP including: (1) CSP reputation ratings-> Accounting-based CFP; (2) CSP reputation ratings-> Perceptual CFP measures; (3) Social audits, CSP processes, and observable outcomes -> Accounting-based CFP; (4) Social audits, CSP processes, and observable outcomes -> Perceptual CFP measures; (5) Authors self-defined CSP-> Accounting-based CFP; (6) Market-based CFP -> CSP reputation ratings; (7) Accountingbased CFP -> CSP disclosures; and (8) Accounting-based CFP -> CSP reputation ratings. Some studies (e.g. Siregar and Bachtiar, 2010) suggest a negative relationship, but in analyzing these studies against all the others using the statistical analysis, the overall relationships in statistical terms could be changed to being positive. The confirmation of positive causality of some decomposed CSP and decomposed CFP to a certain extent supports the good management theory (Waddock and Graves, 1997), which holds that better performance along various dimensions of CSP itself results in better financial outcomes. In addition, the confirmation of positive causality of some decomposed CFP on decomposed CSP measures to a certain degree supports the slack resources theory (Waddock and Graves, 1997), according to which firms with more slack resources available will be more inclined to engage in CSR and responsiveness.

The significance test results of the relationships of the rest pairs were confirmed as nonsignificant. It can also been seen from Table 5 that the significance test has not been meaningfully conducted on a few pairwise decomposed CSP and CFP owing to only one paper falling in the pair. This could be caused by two factors: (a) the incompleteness of the paper list 
regardless of how rigorous of the processes we have adopted to establish it; or (b) certain areas of relationships having been under-researched and need further investigation. Examination of the bidirectional causality between decomposed CSP and CFP is not undertaken in this paper, owing to the exponentially increased amount of work required to do so. This leaves open whether there is a virtuous or vicious cycle between the decomposed CSP and CFP unanswered.

Although the findings of the mixed relationships appear again between the 'decomposed' CSP and CFP, the specific relationships are actually more useful for practical applications. For example, knowledge about the relationships between some specific and decomposed CSP and CFP aspects can help business executives optimize their CSR strategies to achieve better CSP and CFP with limited financial resources. In general, researchers should not seek to generalize the CSP-CFP link but rather to decompose it. As Ward and Smith (2006) suggest, CSR needs to be localized at both conceptual and operational levels so that it becomes more manageable and embedded within an organization. Likewise, Porter and Kramer (2006) assert that many CSR strategies are ineffective as they consider CSR in a generic way, not in a particular way most appropriate to the firm in question. Lower generality of the relationships does not render them useless; the contextualized link can be an ideal value for a metric, i.e., of a priority area. Executives from other countries, industries, or companies could make their own comparisons and enact CSR practices that are appropriate to their own firms.

\subsection{The effects of space on the CSP-CFP relationship}

As shown in Table 6, researchers have increasingly explored the CSP-CFP relationship in developing countries and around the globe. Cramer (2008), for example, investigates how companies can efficiently implement CSR in international product chains by taking into account the particularities of their supply chain relationships. One reason for this is that, with the deepening of globalization, CSR has travelled to other countries. CSR practices may be brought to a specific country by international companies when business strategies are adopted to achieve competitiveness in host communities. For example, an international construction company may help build hospitals and schools as a philanthropic exercise in a local community when it undertakes other construction business. With heightened CSR awareness 
through globalization, it is not uncommon for a company in one country to have a say in the social welfare of workers in other countries. Coffee companies in highly developed countries, for example, are increasingly promoting fair trade with coffee bean farmers in underprivileged regions. Ciliberti et al. (2008) investigate how small and medium-sized enterprises (SMEs) transfer CSR behaviors to their suppliers that operate in developing countries. The growing global prominence of CSR may also reflect the urgent need for its application in emerging economies such as China, India, Thailand, and Indonesia. Along with the development of these economies, adverse effects such as environment degradation, income disparity, and poor occupational health and safety have been much condemned, and the promotion of CSR is expected to alleviate these problems. Given that CSR involves activities taken by companies in excess of legal requirement, and the fact that companies in developed countries have been striving to meet the already soaring legal expectations, there is a view that developing countries have more potential than those in developed countries to introduce CSR strategies. It is envisaged that research on the CSP-CFP relationship will continue to flourish in developing countries along with the globalization of the world economy.

Table 6 A demography of the countries examined by the reviewed articles

\begin{tabular}{|c|c|c|c|c|c|}
\hline Year & Countries examined & $\begin{array}{l}\text { Number of } \\
\text { articles on } \\
\text { developing } \\
\text { countries }\end{array}$ & $\begin{array}{l}\text { Number of } \\
\text { articles } \\
\text { without } \\
\text { specifically } \\
\text { mentioning } \\
\text { the types of } \\
\text { countries }\end{array}$ & $\begin{array}{l}\text { Number of } \\
\text { articles on } \\
\text { developed } \\
\text { countries }\end{array}$ & Total \\
\hline 2002 & UK, USA & 0 & 0 & 2 & 2 \\
\hline 2003 & Not specified & 0 & 1 & 0 & 1 \\
\hline 2004 & USA & 0 & 2 & 1 & 3 \\
\hline 2005 & India, Pakistan, Sri Lanka, Thailand & 1 & 2 & 0 & 3 \\
\hline 2006 & China, UK, Latin America & 2 & 3 & 1 & 6 \\
\hline 2007 & $\begin{array}{l}\text { China, USA, Europe, Spain, Netherland, } \\
\text { Taiwan, Indonesia }\end{array}$ & 3 & 0 & 3 & 6 \\
\hline 2008 & $\begin{array}{l}\text { Australia, Canada, China, India, Korea, } \\
\text { USA, North America }\end{array}$ & 2 & 4 & 8 & 14 \\
\hline 2009 & $\begin{array}{l}\text { Canada, Dubai, Japan, Indonesia, Spain, } \\
\text { USA, Europe }\end{array}$ & 1 & 8 & 9 & 18 \\
\hline 2010 & $\begin{array}{l}\text { Brazil, India, Indonesia, Korea, Taiwan, } \\
\text { Turkey, Europe }\end{array}$ & 6 & 9 & 3 & 18 \\
\hline 2011 & $\begin{array}{l}\text { China, Dubai, German, Japan, UK, Korea, } \\
\text { Spain, Europe, North America }\end{array}$ & 2 & 5 & 6 & 13 \\
\hline Total & & 17 & 34 & 33 & 84 \\
\hline
\end{tabular}


Another trend is that researchers have sought answers to the CSP-CFP relationship in the context of a more specific background (e.g. a particular country, or a given industry). For example, Jenkins and Yakovleva (2006) offer a detailed review of the development of CSR in the global mining industry. Lambooy (2010) considers a very particular setting, investigating CSR in water use. The flaws in making comparisons between different international business giants across different jurisdictions have gradually been recognized; the political, economic, social, technological, environmental and legal (PESTEL) background against which companies operate differs from one country to another and from one industry to another. The implications of this research trend are twofold. Firstly, researchers may have to develop their own CSR measures in a study that analyzes the CSP-CFP relationship. As discussed in previous sections, given that there is no consensus definition of the CSR term, studies that have explored the empirical CSP-CFP link often circumvent the measuring problem by using aggregated CSR indices established by other parties, such as the KLD index, and the FTSE KLD 400 Social Index. However, the majority of the companies on the US-led indices are from developed countries. Therefore, using these pre-existing indices as simple surrogates to measure CSR of companies in a developing country is not entirely viable. Secondly, investigating the CSP-CFP relationship in a given jurisdiction or a given industry requires comprehensive understanding of the impacts caused by the specific PESTEL background. This resonates with Saether and Aguilera (2008), who point out the significant differences between the Canadian, the Continental European and the Anglo-Saxon approaches to CSR. The impact of space change is difficult to assess by simply adding one or two control variables in the CSP-CFP equation. Instead, the inquiry should be linked to the different institutional environment, company culture, and customer preferences. Given the above challenges, research examining the CSPCFP relationship in developing countries and in a specific industrial setting is set to proliferate.

\subsection{The effects of time on the CSP-CFP relationship}

Another research trend identified from this critical analysis is that studies (54 out of the 84) are starting to consider the time effect on the CSP-CFP relationship. These studies regard the relationship as a dynamic process that will change over time. In analyzing the time effects, statistical models have been employed such as the lag regression model (used by most studies), 
the two-stage least squares analysis (Makni et al., 2009; Wang et al., 2008a), the partial least squares model (Brammer et al., 2005), the structural equation model (Bruce et al., 2004; Chang and Kuo; 2008, Boehe and Barin, 2010) and the time series model (Becchetti et al., 2008; Peters and Mullen, 2009; Callado-Muñoz and Utrero-González, 2011). These models are often data greedy but the continued flourishing of CSR research has made it possible to engage these more sophisticated models.

Although the majority of the efforts researching time effects on the CSP-CFP relationship have resulted in positive, negative, or non-significant relationships, some interesting findings have been discovered. Barnett and Salomon (2006) observe a curvilinear (U-shaped) relationship in the specific context of the Social Responsibility Investment (SRI) fund market. That is, as the number of social screens used by an SRI fund increases, financial returns decline at first but then rebound as the number of screens reaches a maximum (Barnett and Salomon, 2006). Wang et al. (2008a) suggest an inverse U-shape to capture the impact of corporate philanthropy on financial performance. That is, an increase in corporate philanthropy to a certain level is beneficial for financial performance, but after that level financial performance should level off and eventually decline. Similarly, Park and Lee (2009) identify a U-shaped effect of CSR reputation rating on accounting-based CFP, although no significant impact on market-based CFP was found. Wagner (2009) analyzes in this direction toward the time effect on CSP-CFP relationship, but only observes a non-linear relationship with insufficient evidence to draw a Ushaped time-effect curve. Recently, Inoue and Lee's (2011) work reveals that the short-term and long-term impact of CSR on CFP differ as to time, industry and CSR measures. In brief, the time effect on the CSP-CFP relationship as a new trend has been gradually recognized and explored in empirical studies over the past ten years.

There are theoretical and practical implications in seeking to fully understand how the CSPCFP relationship evolves over time. As held by the 30 studies not considering time effect on the relationship, the notion that CSR will have an immediate and unchanging impact on CFP may be flawed. It takes time for CSR to have an effect on CFP, or vice versa. Moreover, there can be threshold levels and saturation points before and after which CSR does not exercise any impact on the CFP, or vice versa. In this light, lag regression or time series models have 
increasingly appeared in publications over the past decade. In the practical sphere, this line of inquiry helps explain why chief executive officers (CEOs) of many companies hesitate to fully engage in CSR, given pressure to effectively maximize profitability for shareholders in short term. Further explorations of the time effect on the CSP-CFP relationship are certainly promising as a research direction.

\section{Conclusions and future research}

Researchers over the past decades have endeavored to identify the links between CSP and CFP, partially with the aim to provide an economic justification for conducting CSR. A plethora of studies over the past forty years have produced 'mixed' results, with positive, negative, or neutral relationships reported between CSP and CFP. Since the milestone summaries contributed by Margolis and Walsh (2001) and Orlitzky et al. (2003), new studies of the CSPCFP nexus have continued to flourish in the past decade.

This paper has examined empirical studies of the CSP-CFP relationship published in the decade between 2002 and 2011. It is found that, despite the enormous amount of relevant studies, the CSP-CFP nexus is still a line of inquiry that remains inconclusive. Researchers have devised new variables to measure 'decomposed' aspects of CSR and CFP given that both are broad constructs. A clear trend is observed in the increasing focus of research into CSPCFP relationships on exploring the links between specific aspects of the two constructs. The previously reported positive relationships between the decomposed CSP and CFP in dual directions are confirmed by most of the studies examined in this paper, while some did argue for a non-significant or a negative relationship. Exploring the decomposed CSP and CFP relationships is observed as a promising direction for future research; CSR needs to be localized at both conceptual and operational levels so that it becomes more manageable and embedded within an organization.

The paper also reveals that researchers have sought answers to the CSP-CFP relationship in the context of a more specified background (e.g. a specific country, or a given industry). CSR has travelled across countries with the deepening of globalization. CSR practices are often brought to a specific country by international companies when business strategies are adopted to 
achieve competitiveness in host communities. Future research may look into the development of different CSR practices, taking into account the unique PESTEL background that epitomizes a country or a given industry. The trends of CSP-CFP nexus research towards specifics are envisaged to continue in the future.

A further research trend identified is that previous researchers have gradually recognized the non-static nature of the CSP-CFP relationship. The traditional notion that CSR will have an immediate and unchanging impact on CFP is observed to be largely flawed. Instead, the effects of implementing CSR take time to materialize on CFP, and vice versa. Further explorations of the time effect on the CSP-CFP relationship, particularly in a quantifiable manner, are therefore recommended as another promising future research direction.

In addition to the above trends, which we believe that researchers should be aware of, the research findings from the literature review are also of significant practical value. With awareness of the relationships between some specific and decomposed CSP and CFP aspects, business executives can develop their CSR strategies towards achieving better CSP and CFP through optimization of the scarce financial resources at hand. Increasing exploration of the nexus between CSP and CFP in a specified background (e.g. a specific country, or a given industry) has significant implications for international business. Competition does not have to involve aggressive, 'hard' strategies; so-called 'soft' strategies, such as CSR, can also facilitate business success in terms of corporate social and financial performance. Last but not the least, the research corroboration of the fact that it takes time for CSR to have an effect on CFP, and vice versa, may help relieve the pressure on business executives to maximize profitability for shareholders in short term, allowing them to be fully involved in CSR strategies and to monitor their effectiveness in the long term.

\section{Acknowledgements}

The work is supported by the Hong Kong Research Grants Council (RGC) General Research Fund (GRF) (Project No.: HKU 749312B). Thanks also go to the anonymous reviewers and the editor for their time and constructive comments. 


\section{References}

References marked with an asterisk indicate the 84 empirical studies included in the review.

*Alan, D. S. 2007. Making the case for the competitive advantage of corporate social responsibility. Business Strategy Series, 8, 186-195.

Allouche, J., Laroche, P. 2005. A meta-analytical investigation of the relationship between corporate social and financial performance. Revue De Gestion Des Ressources Humaines, 57, 8-41.

Andersen, M.L., Dejoy, J. 2011. Corporate social and financial performance: the role of size, industry, risk, R\&D and advertising expenses as control variables. Business and Society Review, 116, 237-256.

*Aras, G., Asli, A., Ozlem, K. 2010. Managing corporate performance. International Journal of Productivity and Performance Management, 59, 229-254.

Barnard, C.I. 1938. The Functions of the Executive. Cambridge, MA: Harvard University Press.

*Barnett, M. L. , Salomon, R. M. 2006. Beyond dichotomy: the curvilinear relationship between social responsibility and financial performance. Strategic Management Journal, $27,1101-1122$

*Becchetti, L., Di Giacomo, S. , Pinnacchio, D. 2008. Corporate social responsibility and corporate performance: Evidence from a panel of US listed companies. Applied Economics, 40, 541-567.

*Ben, B. A., Rettab, B. , Mellahi, K. 2011. Market orientation, corporate social responsibility, and business performance. Journal of Business Ethics, 99, 307-324.

Beurden, P and Gössling, T. 2008. The worth of values - a literature review on the relation between corporate social and financial performance. Journal of Business Ethics, 82, 407424.

*Boehe, D. , Barin Cruz, L. 2010. Corporate social responsibility, product differentiation strategy and export performance. Journal of Business Ethics, 91, 325-346.

*Boesso, G. , Michelon, G. 2010. The effects of stakeholder prioritization on corporate financial performance: An empirical investigation. International Journal of Management, 27, 470-496.

Bowen, H.R. 1953. Social Responsibility of the Businessman. New York: Harper and Row.

*Brammer, S. , Millington, A. 2005. Profit maximisation vs. agency: An analysis of charitable 
giving by UK firms. Cambridge Journal of Economics, 29, 517-534.

*Bruce, S., Sara, A. M. , Barbara, R. B. 2003. Comparing big givers and small givers: Financial correlates of corporate philanthropy. Journal of Business Ethics, 45, 195-211.

*Bruce, S., Sara, A. M. , Barbara, R. B. 2004. Having, giving, and getting: Slack resources, corporate philanthropy, and firm financial performance. Business and Society, 43, 135161.

Bryman, Al. and Bell, E. 2011. Business Research Method, 3rd Edition. Oxford University Press: Oxford.

*Busch, T. , Hoffmann, V. 2011. How hot is your bottom line? Linking carbon and financial performance. Business and Society, 50, 233-265.

*Byus, K., Deis, D. , Ouyang, B. 2010. Doing well by doing good: Corporate social responsibility and profitability. Sam Advanced Management Journal, 75, 44-55.

*Callado-Muñoz, F., Utrero-González, N. 2011. Does it pay to be socially responsible? Evidence from Spain's retail banking sector. European Financial Management, 17, 755787.

*Callan, S. J. , Thomas, J. M. 2009. Corporate financial performance and crporate social performance: An update and reinvestigation. Corporate Social Responsibility and Environmental Management, 16, 61-78.

*Campbell, D., Moore, G. , Metzger, M. 2002. Corporate philanthropy in the UK 1985-2000: Some empirical findings. Journal of Business Ethics, 39, 29-41.

Carroll, A. B. (1991). The pyramid of corporate social responsibility: Toward the moral management of organizational stakeholders. Business Horizons, 34, 39-48.

Carroll, A. B. and Shabana K.M. 2010. The business case for corporate social responsibility: a review of concepts, research and practice. International Journal of Management Review, 12 (1), 85-105.

*Chang, D. , Kuo, L. 2008. The effects of sustainable development on firms' financial performance - An empirical approach. Sustainable Development, 16, 365-380.

*Chen, H., Wang, X. 2011. Corporate cocial responsibility and corporate financial performance in China: An empirical research from Chinese firms. Corporate Governance, 11, 361-370.

${ }^{*}$ Chih, H. L., Chih, H. H. , Chen, T.Y. 2010. On the determinants of corporate social responsibility: International evidence on the financial industry. Journal of Business 
Ethics, 93, 115-135.

Chillida, J.J.C. 2009. Performance Prism, a New Approach to Corporate Social Responsibility. Master thesis, Aarhus School of Business, Aarhus Unversity.

*Choi, J., Kwak, Y. , Choe, C. 2010. Corporate social responsibility and corporate financial performance: Evidence from Korea. Australian Journal of Management, 35, 291-311.

*Choi, T. H. , Jung, J. 2008. Ethical commitment, financial performance, and valuation: An empirical investigation of Korean companies. Journal of Business Ethics, 81, 447-463.

Ciliberti, F., Pontrandolfo, P., Scozzi, B. 2008. Investigating corporate social responsibility in supply chains: a SME perspective. Journal of Cleaner Production, 16, 15, 1579-1588.

Cochran, P. L., Wood, R. A. 1984. Corporate social responsibility and financial performance. Academy of Management Journal, 27 (1), 42-56.

Conine, T. E., and Madden, G. P.1987 'Corporate social responsibility and investment value: The expectational relationship' in Handbook of business strategy 1986/1987 yearbook. W. D. Guth (ed.), 18-1 to 18-9. Boston, MA:Warren, Gorham, \& Lamont.

Cramer, J.M. 2008. Organising corporate social responsibility in international product chains. Journal of Cleaner Production, 16, 3, 395-400.

Crowther, D. 2004. Corporate social reporting: Genuine action or window dressing? In Crowther, D. and Rayman-Bacchus, L. (ed.), Perspectives on Scorporate Social Responsibility, Ashgate Publishing Ltd: England.

Dahlsrud, A. 2008. How corporate social responsibility is defined: an analysis of 37 definitions. Corporate Social Responsibility and Environmental Management, 15(1), 113.

Davidson, W. N. III and D. L. Worrell 1990. A comparison and test of the use of accounting and stock market data in relating corporate social responsibility and financial performance. Akron Business and Economic Review, 21(3), 7-19.

*Delmas, M., Hoffmann, V. H. , Kuss, M. 2011. Under the tip of the iceberg: Absorptive capacity, environmental strategy, and competitive advantage. Business , Society, 50, 116154.

*De-Los-Ángeles Gil-Estallo, M., Giner-De-La- Fuente, F. , Gr Ful-Miquela, C. 2009. Benchmarking corporate social responsibility within Spanish companies. International Advances In Economic Research, 15, 207-225. 
Dolan, P., Shaw, R., Tsuchiya, A. and Williams, A. 2004. QALY maximization and people’s preferences: A methodological review of the literature. Health Economics 14, 2, $197-$ 208.

DTI 2002. Business and Society: Developing Corporate Social Responsibility: Report 2002. London: Department of Trade and Industry.

*Duhe, S. C. 2009. Good management, sound finances, and social responsibility: Two decades of US corporate insider perspectives on reputation and the bottom line. Public Relations Review, 35, 77-78.

Ebner, D., \& Baumgartner, R. J. 2006. The Relationship between Sustainable Development and Corporate Social Responsibility. www.crrconference.org, [retrieved on 17 November 2013].

*El Ghoul, S., Guedhami, O., Kwok, C. C. Y. , Mishra, D. R. 2011. Does corporate social responsibility affect the cost of capital? Journal of Banking and Finance, 35, 2388-2406.

Ellis, P.D. 2010. The Essential Guide to Effect Sizes: An Introduction to Statistical Power, Meta-Analysis and the Interpretation of Research Results. Cambridge University Press.

European Commission (2011). A Renewed EU strategy 2011-14 for Corporate Social Responsibility: Communication from the Commission to the European Parliament, the Council, the European Economic and Social Committee and the Committee of the Regions.

*Fauzi, H. , Idris, K. M. 2009. The relationship of CSR and financial performance: New evidence from Indonesian companies. Issues In Social and Environmental Accounting, 3, 66-87.

*Fauzi, H. 2009. Corporate social and financial performance: Empirical evidence from American companies. Globsyn Management Journal, 3, 25-34.

*Fauzi, H., Mahoney, L. S. , Rahman, A. A. 2007. The link between corporate social performance and financial performance: Evidence from Indonesian Companies. Issues In Social and Environmental Accounting, 1, 149-159.

Freeman, E. 1984. Strategic Management: A Stakeholder Approach. Pitman, Boston, MA.

Friedman, M. 1962. Capitalism and Freedom. University of Chicago Press.

*Gallego-Alvarez, I., Prado-Lorenzo, J.-M., Rodriguez-Dominguez, L. , Garcia-Sanchez, I.-M. 2010. Are social and environmental practices a marketing tool? Empirical evidence for 
the biggest European companies. Management Decision, 48, 1440-1455.

Glaser, B. G. 1965. The constant comparative method of qualitative analysis. Social Problems 12 (4): 436.

*Godfrey, P. C., Merrill, C. B. , Hansen, J. M. 2009. The relationship between corporate social responsibility and shareholder value: An empirical test of the risk management hypothesis. Strategic Management Journal, 30, 425-445.

*Goll, I. , Rasheed, A. A. 2004. The moderating effect of environmental nunificence and dynamism on the relationship between discretionary social responsibility and firm performance. Journal of Business Ethics, 49, 41-54.

*Greig, A. M. 2006. The financial performance of a socially responsible investment over te and a possible link with corporate social responsibility. Journal of Business Ethics, 63, 131148.

Griffin, J. J., Mahon, J. F. 1997. The corporate social performance and corporate financial performance debate: Twenty-five years of incomparable research. Business and Society, 36: 5-31.

*He, Y., Tian, Z. , Chen, Y. 2007. Performance implications of nonmarket strategy in China. Asia Pacific Journal of Management, 24, 151-169.

*Huang, C.J. 2010. Corporate governance, sorporate social responsibility and corporate performance. Journal of Management and Organization, 16, 641-655.

*Hull, C. , Rothenberg, S. 2008. Firm performance: the interactions of corporate social performance with innovation and industry differentiation. Strategic Management Journal, 29, 781.

*Inoue, Y. , Lee, S. 2011. Effects of different dimensions of corporate social responsibility on corporate financial performance in tourism-related industries. Tourism Management, 32, 790-804.

Jacobs, W.L. and Kleiner, B.H. 1995. New developments in measuring corporate performance. Management Research, 18(3-5), 70-77.

Jenkins, H., Yakovleva, N. 2006. Corporate social responsibility in the mining industry: Exploring trends in social and environmental disclosure. Journal of Cleaner Production, 14, 3/4, 271-284.

*Jin-Woo, K. 2010. Assessing the long-term financial performance of ethical companies. 
Journal of Targeting, Measurement and Analysis For Marketing, 18, 199-208.

Jupp, V. 2006. The Sage dictionary of social research methods. Sage Publications Ltd.: London.

*Kang, K. H., Lee, S. , Huh, C. 2010. Impacts of positive and negative corporate social responsibility activities on company performance in the hospitality industry. International Journal of Hospitality Management, 29, 72-81.

*Kobeissi, N. , Damanpour, F. 2007. Corporate responsiveness to community stakeholders effects of contextual and organizational characteristics. Business and Society, 48, 326359.

Kreps, T.J. 1940. Measurement of the social performance of business. In An investigation of concentration of economic power for the temporary national economic committee (Monograph No. 7). Washington, DC: U.S. Government Printing Office.

*Kristoffersen, I., Gerrans, P. , Clark-Murphy, M. 2008. Corporate social performance and financial performance. Accounting, Accountability and Performance, 14, 45-90.

Lambooy, T. 2011. Corporate social responsibility: sustainable water use. Journal of Cleaner Production, 19, 8, 852-866.

*Lee, D., Faff, R. , Langfield-Smith, K. 2009. Revisiting the vexing question: Does superior corporate social performance lead to improved financial performance? Australian Journal of Management, 34, 21-49.

*Lee, S. , Park, S.Y. 2009. Do Socially responsible activities help hotels and casinos achieve their financial goals? International Journal of Hospitality Management, 28, 105-112.

*Lee, S. , Park, S.Y. 2010. Financial impacts of socially responsible activities on airline companies. Journal of Hospitality, Tourism Research, 34, 185-203.

Lewin, A.Y., Sakano, T., Stevens, C.U. and Victor, B. 1995. Corporate citizenship in Japan: survey from Japanese firms. Journal of Business Ethics, 14(2), 83-101.

*Lin, S. L., Chandler, D. , Terrell, R. D. 2007. Assessment on the social responsibility of Taiwan's manufacturing industry. International Journal of Services Technology and Management, 8, 355-388.

*Lopez, M. V., Garcia, A. , Rodriguez, L. 2007. Sustainable development and corporate performance: A study based on the Dow Jones sustainability index. Journal of Business Ethics, 75, 285-300. 
*Luken, R. , Stares, R. 2005. Small business responsibility in developing countries: A threat or an opportunity? Business Strategy and the Environment, 14, 38-53.

*Luo, X. , Bhattacharya, C. B. 2006. Corporate social responsibility, customer satisfaction, and market value. Journal of Marketing, 70, 1-18.

*Mahoney, L., Lagore, W. , Scazzero, J. A. 2008. Corporate social performance, financial performance for firms that restate earnings. Issues In Social and Environmental Accounting, 2, 104-130.

*Makni, R., Francoeur, C. , Bellavance, F. 2009. Causality between corporate social performance and financial performance: Evidence from Canadian firms. Journal of Business Ethics, 89, 409-422.

Margolis, J. D., H. A. Elfenbein, J. P. Walsh. 2007. Does it pay to be good? A meta-analysis and redirection of research on the relationship between corporate social and financial performance. Working paper, Harvard Business School, Cambridge MA.

Margolis, J. D., Walsh, J. P. 2001. People and Profits? the Search for a Link between a Company's Social and Financial Performance. Mahwah, NJ: Lawrence Eribaum.

Margolis, J. D., Walsh, J. P. 2003. Misery loves companies: rethinking social initiatives by business. Administrative Science Quarterly, 268-305.

*May, P. , Khare, A. 2008. An exploratory view of emerging relationship between corporate social and financial performance In Canada. Journal of Environmental Assessment Policy and Management, 10, 239-264.

McGuire, J. B., Sundgren, A., \& Schneeweis, T. 1988. Corporate and social responsibility and firm financial performance. Academy of Management Journal, 31: 854-872.

*Mcpeak, C. , Tooley, N. 2008. Do corporate social responsibility leaders perform better financially? Journal of Global Business Issues, 2, 1-5.

*Mcpeak, C., Devirian, J. , Seaman, S. 2010. Do environmentally friendly companies outperform the market? Journal of Global Business Issues, 4, 61-68.

McWilliams, A., Siegel, D., \& Wright, P. M. 2006. Corporate social responsibility: Strategic implications. Journal of Management Studies, 43: 1-18.

*Mishra, S. , Suar, D. 2010. Does corporate social responsibility influence firm performance of Indian companies? Journal of Business Ethics, 95, 571-601.

*Mittal, R. K., Neena, S. , Archana, S. 2008. An analysis of linkage between economic value 
added and corporate social responsibility. Management Decision, 46, 1437-1443.

*Moneva, J. M. , Ortas, E. 2010. Corporate environmental and financial performance: A multivariate approach. Industrial Management and Data Systems, 110, 193-210.

*Moneva, J. M., Rivera-Lirio, J. M. , Munoz-Torres, M. J. 2007. The corporate stakeholder commitment and social and financial performance. Industrial Management and Data Systems, 107, 84-102.

*Nelling, E. , Webb, E. 2009. Corporate social responsibility and financial performance: the “virtuous circle” revisited. Review of Quantitative Finance and Accounting, 32, 197-209.

*Okamoto, D. 2009. Social relationship of a firm and the CSP-CFP relationship in Japan: Using artificial neural networks. Journal of Business Ethics, 87, 117-132.

Orlitzky, M., Schmidt, F. L., Rynes, S. L. 2003. Corporate social and financial performance: A meta-analysis. Organization Studies, 24, 403-441.

*Ortas, E., Moneva, J.M. 2011. Sustainability stock exchange indexes and investor expectations: Multivariate evidence from DJSI-Stoxx. Spanish Journal of Finance and Accounting, 40, 395-416.

*Pae, J. , Choi, T. H. 2011. Corporate governance, commitment to business ethics, and firm valuation: Evidence from the Korean stock market. Journal of Business Ethics, 100, 323348.

Painter-Morland, M. 2006. Triple bottom-line reporting as social grammar: integrating corporate social responsibility and corporate codes of conduct. Business Ethics: A European Review, 15(4), 352-364.

*Park, S. Y. , Lee, S. 2009. Financial rewards for social responsibility a mixed picture for restaurant companies. Cornell Hospitality Quarterly, 50, 168-179.

*Paul, D. , Barbara, S. 2009. The relationship among board of director characteristics, corporate social performance and corporate financial performance. International Journal of Managerial Finance, 5, 407-423.

Pava, M., Krausz, J. 1996. The association between corporate social responsibility and financial performance: the paradox of social cost. Journal of Business Ethics, 15, 321357.

*Peinado-Vara, E. 2006. Corporate social responsibility in Latin America. The Journal of Corporate Citizenship, 21, 61-69. 
*Peters, R. , Mullen, M. 2009. Some evidence of the cumulative effects of corporate social responsibility on financial performance. Journal of Global Business Issues, 3, 1-14.

Porter, M. E., Kramer, M. R. 2006. Strategy and society. Harvard Business Review, 84, 78-91.

Porter, M.E., Kramer, M.R. 2011. Creating shared value. Harvard Business Review, Jan/Feb $89,1 / 2,62-77$.

Post, J. E. 1991. Research in Corporate Social Performance and Policy. Greenwich, CT: JAI Press.

*Prado-Lorenzo, J. M., Gallego-Alvarez, I., Garcia-Sanchez, I. M. , Rodriguez-Dominguez, L. 2008. Social responsibility in Spain practices and motivations in firms. Management Decision, 46, 1247-1271.

*Prior, D., Surroca, J. , Tribo, J. A. 2008. Are socially responsible managers really ethical? Exploring the relationship between earnings management and corporate social responsibility. Corporate Governance-An International Review, 16, 160-177.

Reimann, B.C. 1975. Organizational effectiveness and management’s public values: A canonical analysis. Academy of Management Journal, 18: 224-241.

*Rettab, B., Ben Brik, A. , Mellahi, K. 2009. A study of management perceptions of the impact of corporate social responsibility on organizational performance in emerging economies: the case of Dubai. Journal of Business Ethics, 89, 371-390.

Rowley, T.J., Berman, S. 2000. A brand new brand of corporate social performance. Business and Society, 39, 397-418.

Saether, K.T., Aguilera, R.V.2008. Corporate social responsibility in a comparative perspective. In Crane, A., et al. the Oxford Handbook of Corporate Social Responsibility. Oxford: Oxford University Press.

*Salama, A., anderson, K. , Toms, J. S. 2011. Does community and environmental responsibility affect firm risk? Evidence from UK panel data 1994-2006. Business Ethics-A European Review, 20, 192-204.

*Schnietz, K.E., Epstein, M.J. 2005. Exploring financial value of a reputation for corporate social responsibility during a crisis. Corporate Reputation Review, 7, 327-345.

*Scholtens, B. 2007. Financial and social performance of socially responsible investments in the Netherlands. Corporate Governance-An International Review, 15, 1090-1105.

*Scholtens, B. 2008. A note on the interaction between corporate social responsibility and 
financial performance. Ecological Economics, 68, 46-55.

*Simpson, W. G. , Kohers, T. 2002. The link between corporate social and financial performance: Evidence from the banking industry. Journal of Business Ethics, 35, 97109.

* Siregar, S. V., \& Bachtiar, Y. (2010). Corporate social reporting: empirical evidence from Indonesia stock exchange. International Journal of Islamic and Middle Eastern Finance and Management, 3(3), 241-252.

Stanley, T. D. 2001. Wheat from chaff: Meta-analysis as quantitative literature review. The Journal of Economic Perspectives 15:131-50.

Stemler, S. 2001. An overview of content analysis. Practical Assessment, Research \& Evaluation, 7(17).

*Stephen, B., Chris, B. , Stephen, P. 2006. Corporate social performance and stock returns: UK evidence from disaggregate measures. Financial Management, 35, 97-116.

*Surroca, J., Trib , J. , Waddock, S. 2010. Corporate responsibility and financial performance: The role of intangible resources. Strategic Management Journal, 31, 463-490.

*Surroga, J. , Tribo, J. A. 2008. Managerial entrenchment and corporate social performance. Journal of Business Finance and Accounting, 35, 748-789.

Ullmann, A. A. 1985. Data in search of a theory: A critical examination of the relationships among social performance, social disclosure, and economic performance of US firms. Academy of Management Review, 540-557.

Visser, W., Matten, D., Pohl, M., and Tolhurst, N. 2010. The A-Z of Corporate Social Responsibility. John Wiley \& Sons Ltd.

Waddock, S.A., Graves, S.B. 1997. The corporate social performance - financial performance link. Strategic Management Journal, 18(4), 303-319.

*Wagner, M. 2009. Innovation and competitive advantages from the integration of strategic aspects with social and environmental management in European firms. Business Strategy and the Environment, 18, 291-306.

*Wang, H., Choi, J. , Li, J. 2008a. Too little or too much? Untangling the relationship between corporate philanthropy and firm financial performance. Organization Science, 19, 143159.

Wang, K., Sewon, O. and Claiborne, M.C. 2008b. Determinants and consequences of 
voluntary disclosure in an emerging market: Evidence from China. Journal of International Accounting, Auditing and Taxation, 17, 14-30.

*Wang, M., Qiu, C. , Kong, D. 2011. Corporate social responsibility, investor behaviors, and stock market returns: Evidence from a natural experiment in China. Journal of Business Ethics, 101, 127-141.

Ward, H., Smith, C. 2006. CSR at a Crossroads: Futures for CSR in the UK to 2015. Russell Press, London.

Wartick, S. L. 1988. How issues management contributes to corporate performance. Business Forum, 13: 16-22.

*Wen, S. , Yuan, F. 2008. An empirical research on relationship between corporate social responsibility and financial performanceanalysis based on stakeholder theory and panel dates. China Industrial Economy, 150-160.

Wolf, F. M. 1986. Meta-Analysis: Quantitative Methods for Research Synthesis. Sage University Paper No. 59.

Wolfe, R. 1991. The use of content analysis to assess corporate social responsibility. James E. Post (ed.), 12, 281-307. Greenwich, CT: JAI Press.

Wood, D. J. 1991. Corporate social performance revisited. Academy of Management Review, 16: $691-718$.

Wood, D.J., Jones, R. E. 1995. Stakeholder mismatching: A theoretical problem in empirical research on corporate social performance. International Journal of Organizational Analysis 3: 229-267.

Wu, M. L. 2006. Corporate social performance, corporate financial performance, and firm size: A meta-analysis. Journal of American Academy of Business, 8(1), 163-171.

*Yang, F. J., Lin, C. W. , Chang, Y. N. 2010. The linkage between corporate social peerformance and corporate financial performance. African Journal of Business Management, 4, 406-413.

*Yu, V., Ting, H.-I. , Wu, Y.-C. J. 2009. Assessing the greenness effort for European firms: A resource efficiency perspective. Management Decision, 47, 1065-1079.

*Zhang, L., Yuan, D., Niu, D. , Jin, Y. 2011. An empirical research on the effect of CSR on CFP----based on listed companies in China. Journal of Northeastern University. Natural Science, 32, 292-296. 
*Zhang, R. , Rezaee, Z. 2009. Do credible firms perform better in emerging markets? Evidence from China. Journal of Business Ethics, 90, 221-237.

*Zheng, L. I. 2006. A study on relation of corporate social responsibility and corporate value: empirical evidence from Shanghai securities exchange. China Industrial Economy, 7783. 